\title{
PARTISIPASI ANGGOTA KELOMPOK TANI DALAM PENGELOLAAN USAHATANI DI DESA MATANI KECAMATAN TUMPAAN
}

\author{
Melgi Yudi Manein \\ Juliana R. Mandei \\ Paulus A. Pangemanan
}

\begin{abstract}
This study aims to determine how the participation of members of farmers in farm management. The research was carried on in the Matani village of District Tumpaan of South Minahasa regency. Data used in this study are primary data and secondary data. The primary data obtained through direct interviews with respondents, while secondary data obtained from the district office Tumpaan. The sampling technique used was proportional stratified random sampling. The group was divided into two strata, farmer groups and farmer groups. The number of samples taken farmer group is three farmer groups, one advanced farmer group (Karisma) and 2 beginners farmer groups (Beringin and Bina Karya), each farmer groups in the capture of 10 members. The variable that is measured in this study is the participation of members of farmers in the planning, implementation, and controlling by using Likert scale. Analysis of the data used in this research is descriptive analysis. The results showed that, the participation of members of farmers in farm management from planning, implementation, and oversight is high.
\end{abstract}

Key words: participation, farmer group, farm management, Matani Village, South Minahasa

\begin{abstract}
ABSTRAK
Penelitian ini bertujuan untuk mengetahui bagaimana partisipasi anggota kelompok tani dalam pengelolaan usahatani. Penelitian ini di laksanakan di Desa Matani Kecamatan tumpaan Kabupaten Minahasa Selatan. Jenis data yang digunakan dalam penelitian ini adalah data primer dan data sekunder. Data primer diperoleh melalui wawancara langsung dengan responden, sedangkan data sekunder diperoleh dari kantor kecamatan Tumpaan. Teknik pengambilan sampel yang digunakan adalah proporsional stratified random sampling. Kelompok dibagi dalam dua strata yaitu kelompok tani lanjut dan kelompok tani pemula. Jumlah sampel kelompok tani yang diambil adalah 3 kelompok tani yang terdiri dari yaitu 1 kelompok tani lanjut (Karisma) dan 2 kelompok tani pemula (Beringin dan Bina Karya), masing-masing kelompok tani di ambil 10 anggota. Variabel yang di ukur dalam penelitian ini adalah partisipasi anggota kelompok tani dalam tahap perencanaan, pelaksanaan, dan pengawasan dengan menggunakan Skala Likert. Analisis data yang digunakan dalam penelitian ini adalah analisis deskriptif. Hasil penelitian menunjukan bahwa,partisipasi anggota kelompok tani dalam pengelolaan usahatani mulai dari tahap perencanaan, pelaksanaan, dan pengawasan tergolong tinggi.
\end{abstract}

Kata kunci: partisipasi, kelompok tani, pengelolaan usahatani, Desa Matani, Minahasa Selatan

\section{PENDAHULUAN}

\begin{tabular}{|c|c|c|}
\hline \multicolumn{3}{|c|}{ Latar Belakang } \\
\hline Beruba & & paradigma \\
\hline $\begin{array}{l}\text { mbangunan } \\
\text { mokratisasi }\end{array}$ & $\begin{array}{l}\text { nasional } \\
\text { dan }\end{array}$ & $\begin{array}{r}\text { ke arah } \\
\text { desentralisasi, }\end{array}$ \\
\hline
\end{tabular}

keseluruhan proses dan program pembangunan. Pemberdayaan dan partisipasi muncul sebagai dua kata yang banyak diungkapkan ketika berbicara tentang pembangunan. Meskipun demikian, pentingnya pemberdayaan dan partisipasi masyarakat belum sepenuhnya dihayati dan dilaksanakan oleh stakeholders pem- 
bangunan, baik dari kalangan pemerintah, swasta, LSM, dan masyarakat.

$$
\text { Pada dasarnya partisipasi }
$$

didefinisikan sebagai keterlibatan mental atau pikiran dan emosi atau perasaan seseorang di dalam situasi kelompok yang mendorongnya untuk memberikan sumbangankepada kelompok dalam usaha mencapai suatu tujuan.Keterlibatan aktif dalam berpartisipasi, bukan hanya berarti keterlibatan jasmaniah semata. Partisipasi dapat diartikan sebagai keterlibatan pikiran, emosi, atau perasaan seseorang dalam situasi kelompok yang mendorongnya untuk memberikan sumbangan kepada kelompok dalam usaha mecapai tujuan.

Secara umum, kelompok tani dibentuk untuk memecahkan permasalahan yang dihadapi petani yang tidak bisa diatasi secara individu, kelompok tani dapat dibentuk secara swadaya maupun atas dasar kepentingan kebijakan dari Pemerintah melalui Dinas Pertanian. Kegiatan perekonomian pada umumnya sangat ditentukan oleh sektor pertanian, sehingga pembangunan yang menonjol juga berada pada sektor pertanian. Salah satu cara untuk lebih menunjang pembangunan pertanian adalah dengan cara pengembangan kelompok tani yang ada di desa-desa maupun di kelurahan.

Pengembangan kelompok tani dilaksanakan dengan menumbuhkan kesadaran petani, dimana keberadaan kelompok tani tersebut dilakukan dari petani, oleh peatani, dan untuk petani. Pengembangan kelompok tani perlu dilaksanakan dengan nuansa peran (variasi atau perbedaan peran) dari anggota kelompok sehingga prinsipkesetaraan, transparasi, tanggungjawab, serta kerjasama menjadi muatan baru dalam pemberdayaan petani. Kelompok tani terbentuk atas dasar adanya kesamaan kepentingan diantara petani menjadi kelompok tani tersebut dan memiliki kemampuan untuk melakukan akses kepada seluruh sumberdaya alam, manusia, modal, informasi, serta sarana dan prasarana dalam mengemban usaha tani yang dilakukannya (Syamsu, 2007).

Desa Matani merupakan salah satu desa yang ada di Kecamatan Tumpaan
Kabupaten Minahas dengan luas 177 hektar yang terdiri dari lahan sawah 40 hektar, lahan kering 90(Ha), pantai dan perairan umum 47(Ha). Dalam upaya meningkatkan ketahanan pangan, peran Kelompok tani dan partisipasi masyarakat di pedesaan sangat besar dalam mendukung dan meningkatkan berbagai program pemerintah.

Luas lahan di Desa Matani mulai berkurang dari Tahun ke Tahun, hal itu membuat motifasi dan partisipasi petani mulai berkurang. Di Desa Matani terdapat 8 kelompok tani yang terbagi atas dua kelas, dimana Kelompok tani kelas pemula terdiri dari 7 Kelompok dan kelas lanjut 1 Kelompok. Jumlah anggota Kelompok tani di Desa Matani berjumlah 15-20 petani dan kegiatan usahatani utama adalah padi sawah.

Partisipasi menurut Hoofsteede yang dikutip oleh Khairuddin dalam Purbathin (2010) berarti "The taking part in one or more phases of the process" atau mengambil bagian dalam suatu tahap atau lebih dari suatu proses, dalam hal ini proses pembangunan. strategi yang sangat potensial dalam rangka meningkatkan ekonomi, sosial dan transformasi budaya. Proses ini, pada akhirnya akan dapat menciptakan pembangunan yang berpusat pada rakyat.

Menurut Purba dalam Mononimbar (2010), proses partisipasi yang dimaksud sesungguhnya adalah keterlibatan masyarakat secara menyeluruh mulai dari tahap perencanaan, pelaksanaan, pengawasan dan evaluasi. Tahap perencanaan adalah suatu proses atau kegiatan dalam rangka menyusun rencana kegiatan dengan demikian, rencana adalah segala hal yang belum dilakukan tetapi diharapkan akan dilakukan. tahap pelaksanaan adalah tindak lanjut atau implementasi dari apa yang dilaksanakan, sedangkan tahap evaluasi adalah memberikan kesempatan bagi orang luar dan orang dalam untuk berhenti dan merefleksikan kegiatan yang telah lalu dengan tujuan untuk membuat keputusan langkah selanjutnya. Partisipasi berbasis masyarakat adalah suatu proses aktif dimana penduduk desa secara langsung ikut serta dalam merencanakan, melaksanakan dan mengevaluasi proyek atau program pembangunan yang mereka miliki dengan 
tujuan untuk menumbuhkan kemandiriannya, meningkatkan pendapatannya dan pengembangan (Dien, 2012).

Menurut Sutarno NS (2004), perencanaan diartikan sebagai perhitungan dan penentuan tentang apa yang akan dijalankan dalam rangka mencapai tujuan tertentu, dimana menyangkut tempat, oleh siapa pelaku itu atau pelaksana dan bagaimana tata cara mencapai itu. Perencanaan merupakan suatu proses mempersiapkan serangkaian pengambilan keputusan untuk dilakukanya tindakan dalam mencapai tujuan organisasi, dengan dan tanpa menggunakan sumbersumber yang ada. Adapun aspek perencanaan meliputi: (1)Apa yang dilakukan? (2)Siapa yang melakukan? (3)Di mana akan melakukan?(4)Apa saja yang diperlikan agar tercapainya tujuan dapat dilakukan? (5)Bagaimana melakukannya? (6)Apa saja yang dilakukan agar tercapainya tujuan dapat maximum?.Perencanaan merupakan kegiatan yang akan dilakukan di masa depan dalam waktu tertentu untuk mencapai tujuan tertentu pula. Sebuah perencanaan yang baik adalah yang rasional, dapat dilaksanakan dan menjadi panduan langkah selanjutnya. Oleh karena itu, perencanaan tersebut sudah mencapai permulaan pekerjaan yang baik dariproses pencapaian tujuan organisasi.Berdasarkan uraian diatas, perencanaan pada hakekatnya merupakan proses pemikiran yang sistematis, analisis, dan rasional untuk menentukan apa yang akan dilakukan, bagaimana melakukanya, siapa pelaksananya, dan kapan kegitan tersebut harus dilakukan.

Arnstein dalam Azhari (2011), kategori tingkat partisipasi masyarakat dapat dibagi sebagai berikut:

a. Partisipasi Rendah (Nonparticipation), klasifikasi ini dikatakan sebagai bukan peran serta, masyarakat hanya dijadikan sebagai obyek suatu kegiatan.

b. Partisipasi Sedang (Tokenism), klasifikasi pada level ini menurut Arnstein adalah masuk ke dalam derajat Penghargaan dan Mengalah, yaitu saat masyarakat sudah diajak bicara tentang keinginannya dan gagasannya, tetapi keputusan apa yang akan diambil sepenuhnya berada di tangan pemerintah.

c. Partisipasi Tinggi (Citizen Power), klasifikasi yang dimaksud adalah apa yang sebenarnya ada dalam gagasan Arnstein tentang peran serta masyarakat itu sendiri, yaitu pada derajat kekuasaan masyarakat dimana sudah terjadi pembagian hak, tanggung jawab dan wewenang antara masyarakat dan pemerintah dalam pengambilan keputusan. Jadi peran serta masyarakat seharusnya dirumuskan sebagai mengambil bagian dalam menentukan hal-hal yang menyangkut atau mempengaruhi hidup dan penghidupan masyarakat itu sendiri.

Untuk mengukur tingkat partisipasi masyarakat dapat dilakukan dengan mengukur tingkat partisipasi individu atau keterlibatan individu dalam kegiatan bersama-sama yang dapat diukur dengan skala yang dikemukakan oleh slamet dalam Yulianty (2005), yaitu: (1)Kea nggotaan dalam organisasi (2)Kehadiran di dalam pertemuan, (3)Sumbangansumbangan(4)Keanggotaan di dalam Kepengurusan (5)Kedudukan anggota, di dalam kepengurusan.

Berdasarkan partisipasi individu tersebut, maka dapat diklasifikasikan skala yang digunakan sebagai variabel untuk mengukur partisipasi anggota Kelompok Tani terhadap pengelolaan usahatani

a. Partisipasi dalam tahap perencanaan meliputi: (1) Tingkat kehadiran dalam rapat/pertemuan; (2) Keaktifan dalam mengajukan saran/usul; (3) pengambilan keputusan

b. Partisipasi dalam tahap pelaksanaan meliputi partisipasi dalam bentuk tenaga dalam kegiatan Persemaian, pengolahan tanah, penanaman, pemupukan, penyiangan, pemberantasan hama dan penyakit, panen dan pasca panen

c. Partisipasi dalam tahap pengawasan.

\section{Rumusan Masalah}

Berdasarkan latar belakang di atas yang menjadi masalah petani di desa Matani yaitu bagaimana patisipasi anggota Kelompok tani dalam pengelolaan usahatani. 


\section{Tujuan Penelitian}

Penelitian ini bertujuan untuk mengetahui tingkat partisipasi anggota Kelompok tani dalam pengelolaan usahatani di Desa Matani.

\section{METODOLOGI PENELITIAN}

Waktu Dan Lokasi Penelitian

Penelitian ini dilaksanakan di Desa Matani, Kecamatan Tumpaan Kabupaten Minahasa Selatan selang bulan April sampai Juli 2016

\section{Jenis dan Sumber Data}

Jenis data yang digunakan yaitu data primer dan data sekunder Data primer diperoleh dengan melakukan wawancara langsung kepada responden. Data Sekunder diperoleh dari kantor kecamatan Tumpaan.

\section{Metode Pengambilan Sampel}

Teknik pengambilan sampel yang digunakan adalah proporsional stratified random sampling. Kelompok dibagi dalam dua strata yaitu kelompok tani lanjut dan kelompok tani pemula . Kelompok tani lanjut diambil satu sampel dan kelompok tani pemula diambil 2 sampel. Dari masingmasing sampel kelompok tani di ambil 10 anggota untuk di jadikan sampel.

\section{Konsep Pengukuran Variabel}

Pengukuran variabel dalam penelitian ini mencakup tingkat partisipasi anggota kelompok tani dalam kegiatan pengelolaan usahatani, yaitu tahap perencanaan, pelaksanaan, dan pengawasan.

a. Partisipasi pada tahap perencanaan
1) Mengikiti pertemuan
2) Menyampaikan saran
3) Pengambilan keputusan

b. Partisipasi dalam tahap pelaksanaan
d. Persemaian
e. pengolahan tanah
f. Penanaman
g. Pemupukan
h. Penyiangan
i. Pemberantasan hama dan penyakit
j. Panen dan pasca panen
c. Partisipasi pada tahap pengawasan(controlling)

\section{Analisis Data}

Data yang digunakan dalam penelitian ini akan di uji menggunakan analisis secara deskriptif dalam bentuk tabel. Metode dasar yang dipakai dalam penelitian ini metode deskriptif, yaitu suatu metode yang memusatkan perhatiannya pada pemecahan masalah, data yang dikumpulkan disusun, di analisis dan di simpulkan. Pelaksanaan dari penelitian ini menggunakan metode survey (Surakhmad 1991).

Analisis data juga menggunakan Skala Likert. Menurut Ridwan (2010) Untuk mengukur sikap akan disusun beberapa pertanyaan dengan total responden 30 orang yang terbagi dalam 3 kelompok tani, dimana masing-masing kelompok diambil 10 orang. Setiap jawaban dihubungkan dengan bentuk pernyataan atau dukungan sikap yang diungkapkan dengan kata-kata berikut;

$\begin{array}{ll}\text { Sangat aktif } & \text { : skor } 5 \\ \text { Aktif } & : \text { skor } 4 \\ \text { Cukup aktif } & : \text { skor } 3 \\ \text { Kurang aktif } & \text { : skor } 2 \\ \text { Tidak aktif } & \text { : skor } 1\end{array}$

Dengan cara perhitungan skor masingmasing pertanyaan:

Jumlah Skor Tiap Kriterium = Capaian Skor x Jumlah Responden

Untuk;

$$
\begin{aligned}
& \mathrm{S} 1=5 \times 30=150 \\
& \mathrm{~S} 2=4 \times 30=120 \\
& \mathrm{~S} 3=3 \times 30=90 \\
& \mathrm{~S} 4=2 \times 30=60 \\
& \mathrm{~S} 5=1 \times 30=30
\end{aligned}
$$

Jumlah skor ideal untuk setiap pernyataan (skor tinggi) $=150$

Jumlah skor rendah $=30$ 
Interprestasi nilai :

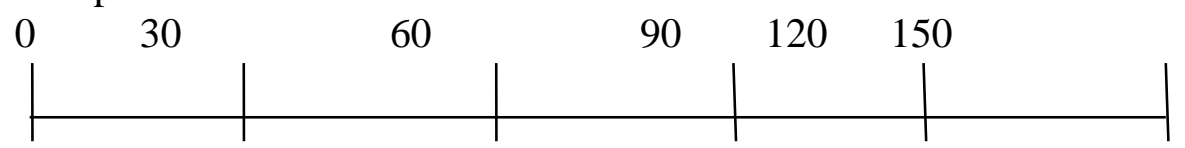

Tidak Aktif Kurang Aktif Cukup AktifAktifSangat Aktif

Analisis data yang digunakan merupakan analisis deskriptif yang dianalisis dengan menggunakan skala pengukuran Likert Scale dimana menurut Ridwan (2010) adalah sebagai berikut :

Tingkat Sikap $=\frac{\text { Jumlah skor hasil pengumpulan data }}{\text { Jumlah skor ideal ( tertinggi) }} \times 100 \%$

$$
\begin{aligned}
& S 1=(150 / 150) \times 100=100 \\
& S 2=(120 / 150) \times 100=80 \\
& S 3=(90 / 150) \times 100=60 \\
& S 4=(60 / 150) \times 100=40 \\
& S 5=(30 / 150) \times 100=20
\end{aligned}
$$

Jumlah skor ideal untuk setiap pernyataan (skor tinggi) $=100$

Jumlah skor rendah $=20$

Interprestasi nilai;

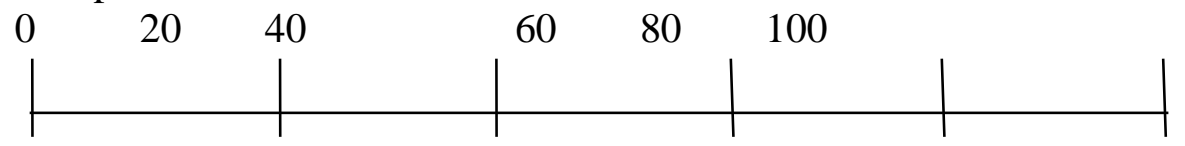

\section{Sangat Rendah Rendah CukupTinggi Tinggi Sangat Tinggi}

\section{HASIL DAN PEMBAHASAN}

\section{Partisipasi Pada Tahap Perencanaan}

Sebelum melaksanaan kegiatan usahatani, setiap kelompok mengadakan pertemuan rutin bersama seluruh anggotanya. Ada yang mengadakan pertemuan sebulan sekali, ada yang dua bulan sekali bahkan ada yang enam bulan sekali. Selain itu ada juga pertemuan antar kelompok tani yang dihadiri oleh ketua, sekretaris dan bendahara kelompok tani. Tabel 1 menunjukkan partisipasi anggota Kelompok Tani dalam mengikuti pertemuan.

Tabel 1 menunjukkan bahwa sebagian besar anggota kelompokj tani aktif dalam menghadiri pertemuan kelompok. .Hasil wawancara yang dilakukan menunjukkan bahwa dari ketiga kelompok tani yang menjadi sampel, masing-masing pengurus inti

\begin{tabular}{|c|c|c|c|c|c|c|}
\hline \multirow{4}{*}{$\begin{array}{c}\text { Partisipas } \\
\text { i }\end{array}$} & \multicolumn{6}{|c|}{ Kehadiran Kelompok Tani } \\
\hline & \multicolumn{2}{|c|}{ Karisma } & \multicolumn{2}{|c|}{ Beringin } & \multicolumn{2}{|c|}{ Bina Karya } \\
\hline & Oran & $(\%$ & Oran & $(\%$ & Oran & $(\%$ \\
\hline & $\mathrm{g}$ & ) & $\mathrm{g}$ & ) & $\mathrm{g}$ & ) \\
\hline Aktif & 6 & 60 & 6 & 60 & 7 & 70 \\
\hline $\begin{array}{l}\text { Kurang } \\
\text { Aktif }\end{array}$ & 4 & 40 & 4 & 40 & 3 & 30 \\
\hline $\begin{array}{l}\text { Tidak } \\
\text { Aktif }\end{array}$ & - & - & - & - & - & - \\
\hline Jumlah & 10 & 10 & 10 & 10 & 10 & 10 \\
\hline & & 0 & & 0 & & 0 \\
\hline
\end{tabular}

yaitu ketua, sekreataris dan bendahara terlibat aktif dalam pertemuan antar kelompok.

Tabel 1. PartisipasiAnggota Kelompok Tani dalam Mengikuti Pertemuan

Dalam setiap setiap pertemuan tentunya masing-masing anggota kelompok memiliki kesempatan untuk memberikan 
usulan atau saran bagi kemajuan kelompok taninya.Dalam pertemuan ada anggota yang selalu memberikan saran ada juga yang tidak memberikan saran. Tabel berikut menunjukkan partisipasi anggota dalam memberikan saran.

Tabel.2 menunjukan bahwa $60 \%$ anggota kelompok tani aktif dalam memberikan saran.
Berdasarkan penelitian yang telah dilakukan, partisipasi anggota kelompok tani dalam tahap perencanaan yang dilihat dari kehadiran dalam pertemuan, menyampaikan saran dan pengambilan keputusan berdasarkan daftar pertanyaan yang diajukan kepada responden, secara keseluruhan untuk 30 responden dari 3 kelompok tani diperoleh nilai 104

Tabel 2. Partisipasi Anggota Kelompok Tani dalam Menyampaikan Saran

\begin{tabular}{lcccccc}
\hline \multirow{2}{*}{ Partisipasi } & \multicolumn{2}{c}{ Karisma } & \multicolumn{2}{c}{ Beringin } & \multicolumn{2}{c}{ Bina Karya } \\
\cline { 2 - 7 } & Orang & $(\%)$ & Orang & $(\%)$ & Orang & $(\%)$ \\
\hline Aktif & 6 & 60 & 6 & 60 & 6 & 60 \\
Tidak Aktif & 4 & 40 & 4 & 40 & 4 & 40 \\
\hline Jumlah & 10 & 100 & 10 & 100 & 10 & 100 \\
\hline
\end{tabular}

Interprestasi nilai :

Gambar 1. Interprestasi Nilai Tahap Perencanaan

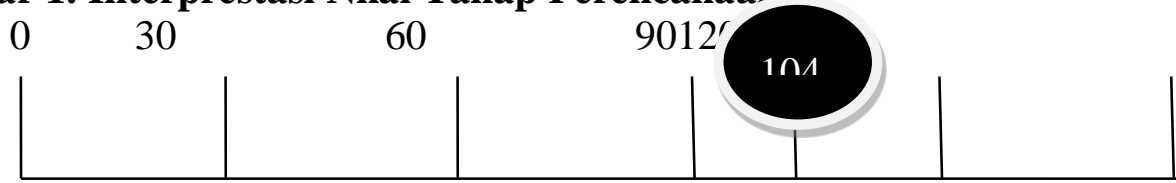

Tidak aktif kurang aktifCukupaktifAktif Sangat aktif

Hal tersebut menandakan bahwa anggota kelompok tani aktif berpartisipasi dalam pengelolaan usahatani khususnya dalam tahap perencanaan.Rata-rata responden dari ketiga kelompok tani tidak selalu mengahadiri pertemuan yang dilaksanakan.Disetiap pertemuan yang dilakukan, sangat jarang ditemui kehadiran dari seluruh anggota kelompok, hampir setiap pertemuan ada saja anggota kelompok yang tidak bisa hadir dengan alasan yang tepat.

\section{Partisipasi Dalam Tahap Pelaksanaan}

Partisipasi anggota kelompok tani dalam tahap pelaksanaan, tergolong tinggi. Tabel 2 menunjukkan partisipasi anggota kelompok tani dalam tahap pelaksanaan.

\begin{tabular}{cccc}
$\begin{array}{c}\text { Tabel 2. } \\
\text { Pelaksanaan }\end{array}$ & Partisipasi & Pada & Tahap \\
\hline $\begin{array}{c}\text { Kelompok } \\
\text { tani }\end{array}$ & $\begin{array}{c}\text { Pelaksanaan } \\
\text { (skor) }\end{array}$ & Rata” & Kategori \\
\hline Karisma & 460 & 46 & $\begin{array}{c}\text { Sangat } \\
\text { aktif } \\
\text { Beringin }\end{array}$ \\
Bina karya & 450 & 45 & $\begin{array}{c}\text { Sangat } \\
\text { aktif } \\
\text { Sangat } \\
\text { aktif }\end{array}$ \\
\hline Total & 4110 & 137 & \\
\hline
\end{tabular}

Secara keseluruhan, berdasarkan hasil penelitian yang dilakukan, dalam tahap pelaksanaan, partisipasi anggota kelompok dalam pengelolaan usahatani termasuk dalam kategori sangat aktif. Hal ini dibuktikan lewat analisis dari hasil wawancara untuk keseluruhan responden dari ketiga kelompok, diperoleh nilai 137 
Interprestasi nilai:

\section{Gambar 2. Interprestasi Nilai Pada Tahap Pelaksanaan}

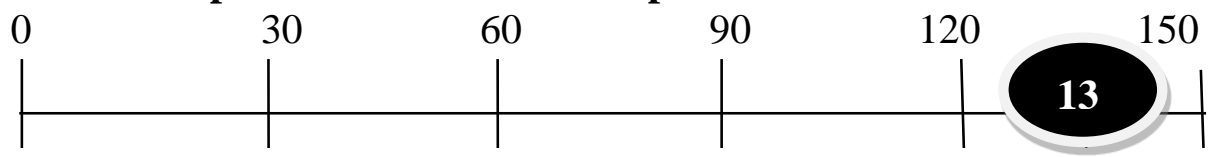

Tidakaktif Kurang aktif cukup aktif Aktif Sangat aktif

Hal tersebut menandakan bahwa anggota kelompok tani berpartisipasi sangat aktif dalam pengelolaan usahatani khususnya dalam tahap pelaksanaan. Rata-rata responden terlibat aktif dalam setiap kegiatan usahatani khususnya dalam tahap pelaksanaan, meskipun ada beberapa anggota yang tidak aktif dalam salah satu kegiatan pada tahap pelaksanaan.

\section{Partisipasi Pada Tahap Pengawasan \\ (Controlling)}

Tahap pengawasan merupakan salah satu tahap yang penting yang perlu dilakukan guna mengawasi setiap kegiatan yang dilakukan oleh anggota kelompok tani dalam pengeloaan usahatani.Dalam tahap pengawasan ini, biasanya dilakukan oleh ketua kelompok, namun ada juga anggota yang terlibat dalam kegiatan pengawasan.Hasil penelitian menunjukkan untuk kelompok tani karisma dan kelompok tani bina karya terdapat 3 orang yang aktif dalam kegiatan pengawasan sedangkan untuk kelompok tani beringin terdapat 2 orang yang aktif.

Secara keseluruhan, berdasarkan hasil penelitian yang dilakukan, dalam tahap pengawasan, partisipasi anggota kelompok dalam pengelolaan usahatani termasuk dalam kategori aktif. Hal ini dibuktikan lewat analisis dari hasil wawancara untuk keseluruhan responden dari ketiga kelompok, diperoleh nilai 104.

Interprestasi nilai:

\section{Gambar 3. Interprestasi Nilai Tahap Pengawasan}

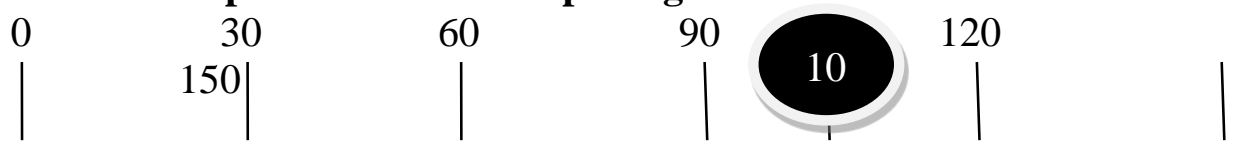

Tidak aktif Kurangaktif Cukup aktif

Aktif

Sangat Aktif

Hal tersebut menunjukan bahwa anggota kelompok tani berpartisipasi aktif dalam pengelolaan usahatani khususnya dalam tahap pengawasan.Rata-rata responden terlibat aktif dalam setiap kegiatan usahatani khususnya dalam tahap pengawasan.

Berdasarkan hasil penelitian yang telah dilakukan, maka dapat dilihat untuk partisipasi anggota kelompok tani dalam pengelolaan usahatani mulai dari tahap perencanaan, tahap pelaksanaan dan tahap pengawasan dengan menggunakan analisis berdasarkan daftar pertanyaan lewat pengukuran skala likert, maka tingkat partisipwasi anggota kelompok tani diperoleh nilai 76,67 .

Interprestasi nilai 


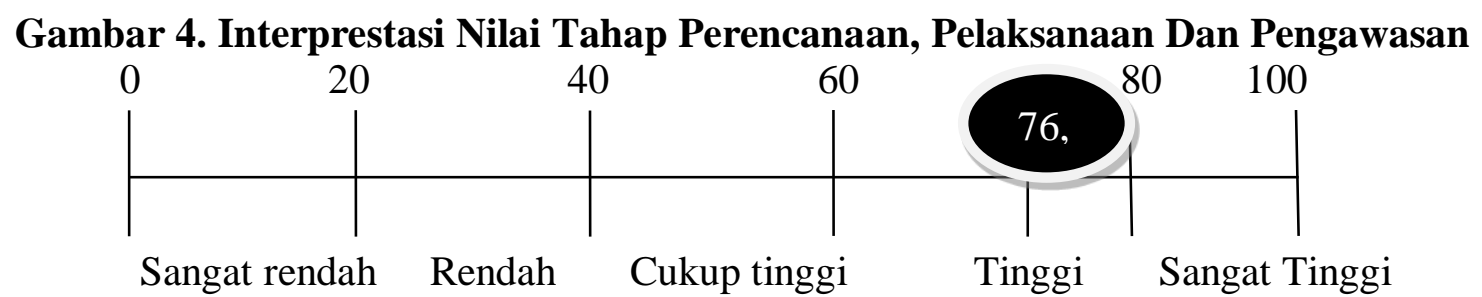

Hal tersebut menunjukkan tingkat partisipasi anggota kelompok tani dalam kegiatan pengelolaan usahatani, berdasarkan hasil perhitungan dengan menggunakan skala likert, tingkat partisipasi anggota kelompok tani dalam pengelolaan usahatani masuk dalam kategori tinggi.

\section{KESIMPULAN DAN SARAN}

\section{Kesimpulan}

Partisipasi anggota kelompok tani dalam pengelolaan usahatani mulai dari tahap perencanaan, tahap pelaksanaan dan tahap pengawasan tergolong tinggi.

Perlu ada upaya dari pengurus
kelompok untuk merangsang anggota
kelompok yang tidak aktif agar turut serta
dalam seluruh kegiatan pengelolaan
usahatani.

\section{DAFTAR PUSTAKA}

Dien. Y. 2012, Partisipasi Masyarakat Terhadap Program Nasional Pemberdayaan Masyarakat Mandiri Perdesaan Didesa Kauditan II Kecamatan Kauditan Kabupaten Minahasa Utara, Fakultas Pertanian Unsrat Manado.

Khairuddin, 2000. Pembangunan Masyarakat Tinjauan Aspek : Sosiologi Ekonomi dan Perencanaan. Liberty. Yogjakarta.
Kristianto, A. W. 2013, Peningkatan Partisipasi Masyarakat Dalam Pembangunan Infrastruktur Jalan (Studi Kasus Pelaksanaan Program Pembangunan Infrastruktur Pedesaan (PPIP) di Desa Campurejo Kecamatan Panceng Kabupaten Gresik).Tesis. Jakarta.

Mononimbar. M. H. 2010. Partisipasi anggota kelompok tani dalam kegiatan sekolah lapangan pengelolaan tanaman terpadu (SL-PTT) jagung. Fakultas Pertanian Unsrat Manado.

.Sutarno, NS. Perpustakaan dan Masyarakat, Jakarta: Yayasan Ohor Indonesia, 2004

Syamsu, J, A. 2007. Memberdayakan Kelompok Tani.

Yuliaty. M. 2005,Partisipasi Masyarakat Dalam Memelihara Benda Cagar Budaya Di Pulau Penyengat Sebagai Upaya Pelestarian Warisan Budaya Melayu, Tesis, Universitas Diponegoro Semarang 